\title{
Development of Ice Cover in Water Areas during Methane
}

\author{
Petr Vladimirovich Lushvin ${ }^{1}$, Marina Olegovna Buyanova ${ }^{2}$ \\ ${ }^{1}$ Independent Researcher, Moscow, Russia \\ ${ }^{2}$ The Faculty of Law, Higher School of Economics, Moscow, Russia \\ Email: ${ }^{\star}$ lushvin@mail.ru
}

How to cite this paper: Lushvin, P.V. and Buyanova, M.O. (2021) Development of Ice Cover in Water Areas during Methane. International Journal of Geosciences, 12, 927940.

https://doi.org/10.4236/ijg.2021.129047

Received: July 30, 2021

Accepted: September 27, 2021

Published: September 30, 2021

Copyright $\odot 2021$ by author(s) and Scientific Research Publishing Inc. This work is licensed under the Creative Commons Attribution International License (CC BY 4.0).

http://creativecommons.org/licenses/by/4.0/

\begin{abstract}
In traditional hydrometeorology and ice physics, when analyzing the development of ice, only degree-days of frost are taken into account. Despite the presence of pores in the ice formed during inhomogeneous crystallization and dynamic loads, ice is universally considered monolithic. Situations where ice cannot withstand design loads in frosty conditions are academically inexplicable, although it is common knowledge, for example, porous ice in reeds. Proof of methane accumulations under the ice-fountains of fire over holes in swampy waters. "Culprit" is methane. Methanotrophic microorganisms, structurally and functionally specialize in using it as a source of carbon and energy, and turn monolithic ice into porous, practically without changing its thickness. When rushing, dark products of methanotrophy and detritus raised by gas bubbles appear on the surface of the ice. The albedo of the ice surface decreases, contributing to its melting and the formation of dilutions. The early melting of ice in dilutions and their transformation into vast wormwood is due to methanotrophy products and seismogenic small detritus, which gravitationally slowly settling out of the cold photic layer, thinning it, contributes to an additional insolation warm-up of $2^{\circ} \mathrm{C}-3^{\circ} \mathrm{C}$, freeing the waters from ice months earlier than normal.
\end{abstract}

\section{Keywords}

Monolithic Ice, Methane, Porous Ice, Earthquakes, Methanotrophic Microorganisms

\section{Introduction. Swamp Gas and Ice Cover}

In traditional hydrometeorology and ice physics, when analyzing and predicting the development of ice, only degree-days of frost are taken into account [1]. Despite the presence, as a rule, micro of pores in the ice formed during inhomoge- 
neous crystallization spreading and dynamic loads, ice is universally considered monolithic. References to the need to take into account ice porosity during loads are found mainly only when the air temperature is positive for several days, then it is believed that the ice strength decreases by no more than two to three times. Situations where ice cannot withstand design loads in frosty conditions are academically inexplicable, although it is commonly known, for example, porous ice in reeds, in swamps with pore sizes of $\mathrm{cm}$ (Figure 1). The "culprit", the predictor that determines these phenomena is methane, regardless of the genesis (mantle, from gas hydrates or natural-household-swamp gas). A large-scale example is the appearance of 20.04.2009 circular tens of $\mathrm{km}$ protaline in cohesive Lake Baikal ice after an outbreak of methane concentration in the lower troposphere above Baikal $14 \div 15.04 .2009$ according to the AIRS satellite radiometer (Figure 2) [2] [3]. Proof of methane accumulations under the ice-fountains of fire over the holes in Baikal at the mouth of the river Selengi and on the river Lena.
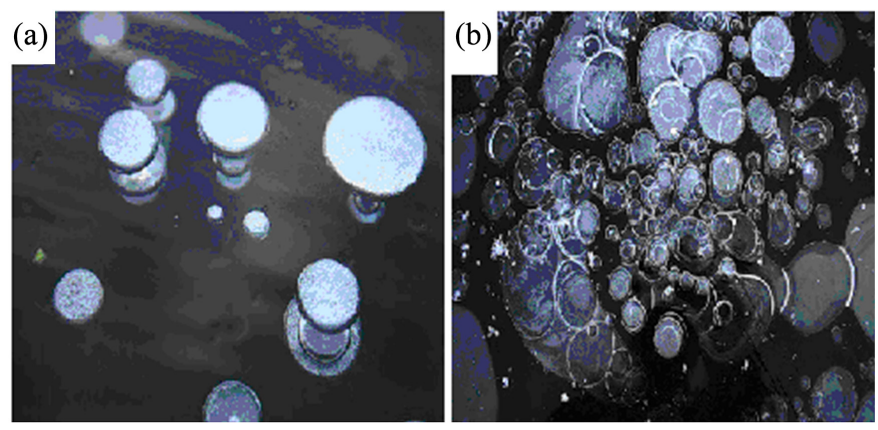

Figure 1. Frozen bubbles of swamp gas in ice $(a, b)$.

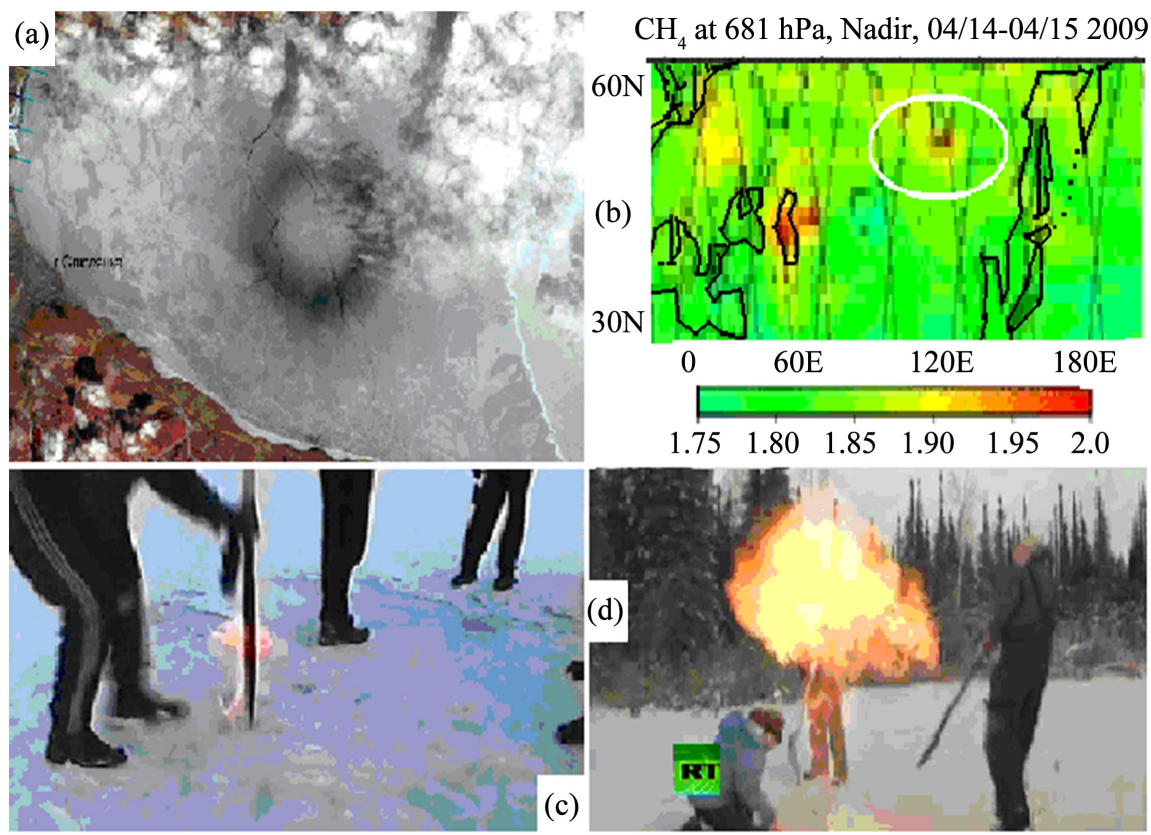

Figure 2. Protalin in Baikal ice 20.04.2009 Landsat-7 (a). An outbreak of methane concentration in the lower troposphere of the Baikal region (b). Set fire to methane in a hole at the mouth of the river. Selengi (c). Set fire to methane on the river. Lena (d). 
Academically unexplained wormwood forms in the ice cover in the south of the Sea of Okhotsk after earthquakes, and forecasts of the sea's release from ice are unstable. Namely, after the earthquake of 04.07.2001 in the Laperuz Strait, an extensive wormwood was formed there by 10.04, after a series of earthquakes in mid-February 2003, wormwood was also formed behind Cape Patience to 3 sound 5.03. In the second half of March, it became visible from microwave satellite data (Figure 3) [4].

There is a feedback $(\mathrm{R}>/-0.73 /)$ between the activation of seismic activity in the southeast of the Sea of Okhotsk from February to early May and the removal of ice from the water area on the southeast coast of Sakhalin Island that ice in late May - early June. In seismic spring, ice lingers until the end of June (Figure 4). Some inconsistencies in antiphase trends are due to the limitations of earthquake catalogs, which contain information about events with magnitudes over 3 $\div 4$. In addition, seismic activity does not unambiguously determine methane degassing and ice development (if one does not take into account the mutual conditionality of seismic and meteorological processes [5]), but only contributes to the large-scale melting of drifting ice.

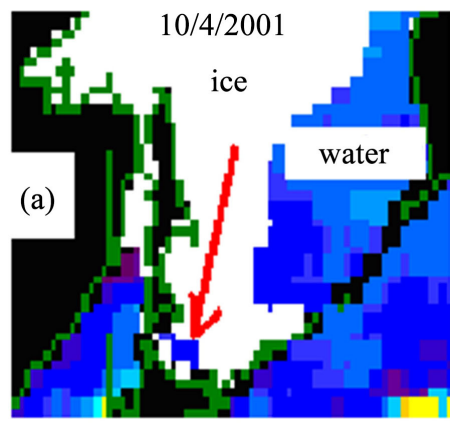

lat. long. magn. date $\begin{array}{llll}46.34 & 143.31 & 3.6 & 07.04 .2001\end{array}$

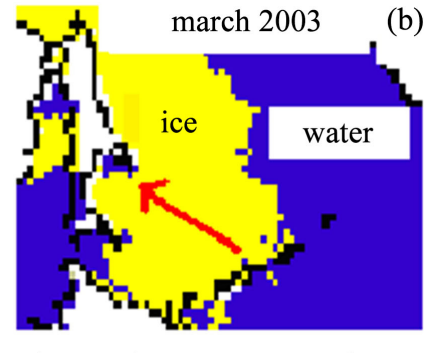

lat. long. magn. date $\begin{array}{llll}48.69 & 142.56 & 4.8 & 13.02 .03\end{array}$ $\begin{array}{llll}48.62 & 142.66 & 3.9 & 13.02 .03\end{array}$ $\begin{array}{llll}48.64 & 142.73 & 4.1 & 19.02 .03\end{array}$

Figure 3. Ice cover and epicenters of earthquakes off the coast of Sakhalin Island in April 2001 (a), February 2003 (b). The arrows indicate the places of earthquakes.

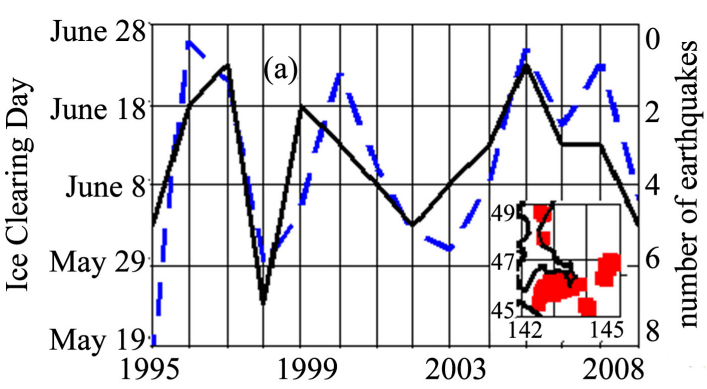

- - Ice Clearing Day

number of earthquakes

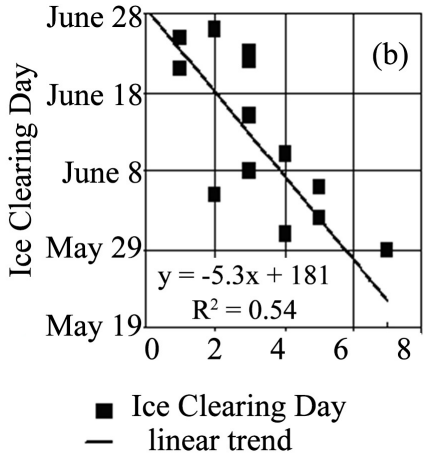

- linear trend

Figure 4. The number of earthquakes and the dates of clearance from the ice of the eastern shore of Sakhalin Island (a, b) (dates of the change of seasons in the region). On the tie-in epicenters of earthquakes. 
In the northeast of the Barents Sea near the North Island of Novaya Zemlya in the surface waters of the Russian Harbor, an abnormally high concentration of methane (Figure 5). Exactly here in a separation on $100 \div 300 \mathrm{~km}$ from clear water of the Barents Sea, as a rule, are observed breeds and ice-holes (Figure 6) of [6] [7]. The development of this is facilitated by heat actively released during bacterial oxidation of methane (positive feedback from $A A R I$ was received for the work on ice [4]).
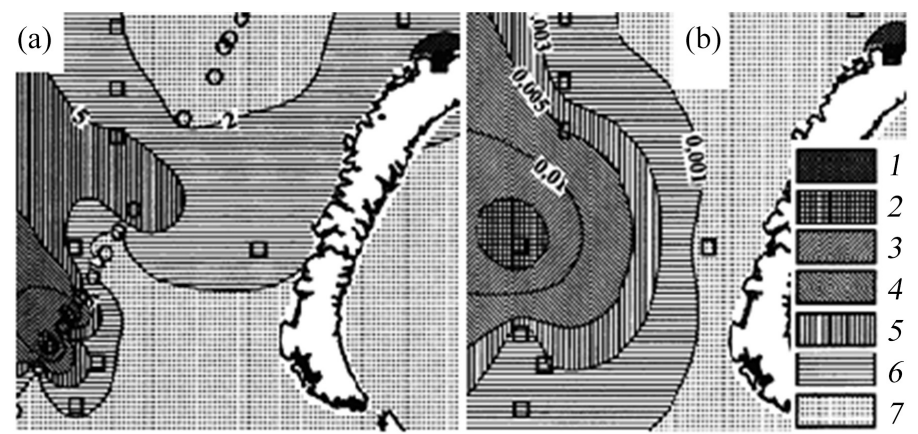

methane concentration, $\mathrm{nmol} / \mathrm{l}: 1)>1700$;

2) 30 - 1700; 3) 20 - 30;4)10 - 20; 5) 5 - 10; 6) 2 - 5; 7)<2; methane oxidation rate, nmole/( 1 day)

1) $>1.5$; 2) $0.015-1.5$; 3) $0.01-0.015$; 4) $0.005-0.01$;

5) $0.003-0.005 ; 6) 0.001-0.003$; 7) $<0.001$

Figure 5. Distribution of methane concentration (a) and rate of microbial oxidation of methane (b) in the surface layer of the water column of the Barents Sea.
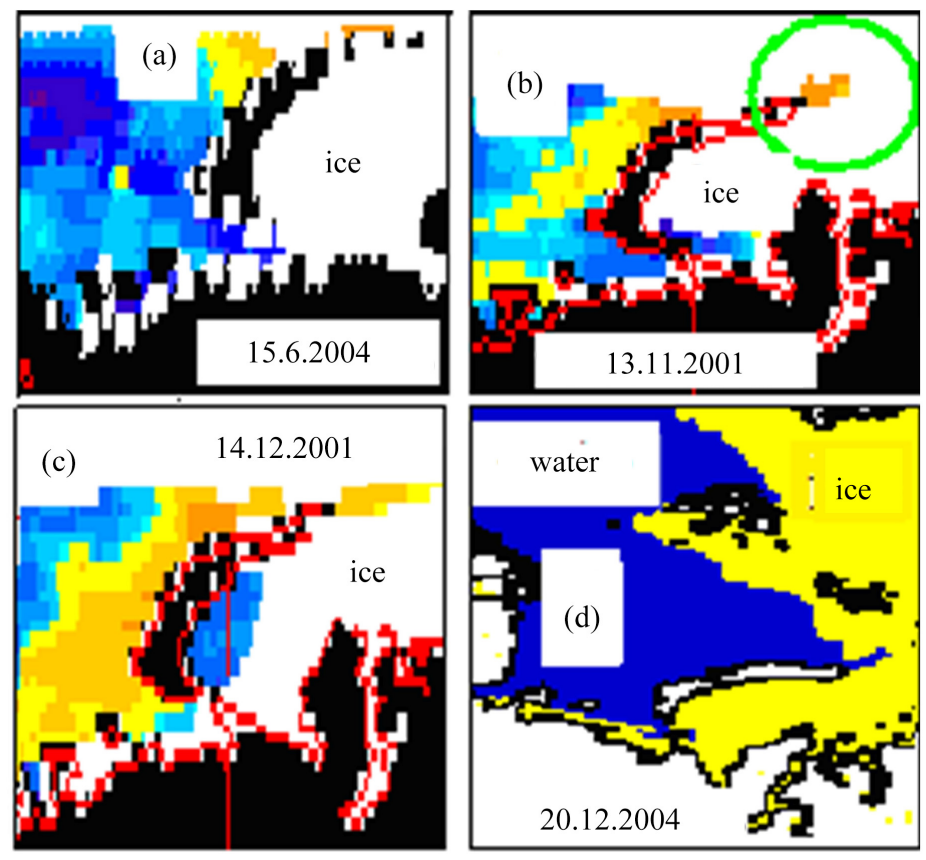

anomaly SST

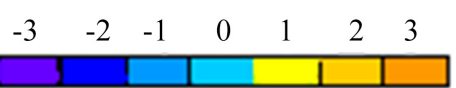

Figure 6. Ice in the Barents and Kara Seas, temperature anomaly (SST). 


\section{Genesis of Methanogenic Conversion of Monolithic Ice to Porous Ice (Which Does Not Withstand Normative Loads According to Degree-Days of Frost)}

In nature, there are methanotrophic microorganisms that structurally and functionally specialize in the use of methane as a source of carbon and energy (according to the determinant of Bergey bacteria-the genera Methylomonas and Methylococcus) [7] [8].

The reaction equation of aerobic microbial methanotrophy, methane oxidation, comes with the release of heat, exothermic:

$$
\mathrm{CH}_{4}+2 \mathrm{O}_{2}=\mathrm{HCO}_{3}^{-}+\mathrm{H}^{+}+\mathrm{H}_{2} \mathrm{O}+814 \mathrm{~kJ} \text {. }
$$

Note that when methane burns, almost the same energy is released $(890 \mathrm{~kJ})$, the difference in reaction rate.

Observations of temperature gradients in methane sipes and flares give conflicting results [9] [10], although analytical reactions unambiguously indicate the warming up of the medium during aerobic oxidation. The heat generated by the oxidation of 2 grams of methane is sufficient to boil a glass of water. The inconsistency of full-scale data on thermal phenomena in methane yields is associated with the "human factor". Observations are mainly made in the summer over the leap layer, where dynamic factors prevail over chemical ones. The situation considered above at the Russian Harbour where at concentration of methane over $1000 \mathrm{n} \mathrm{mol} /\left(\mathrm{l}^{\star}\right.$ day $)$ is allocated from this, surface water is warmer concerning a background on $2^{\circ} \mathrm{C} \div 3^{\circ} \mathrm{C}$ (Figure 5). To isolate thermal chemical components, observations in the bottom sediments of Baikal were analyzed [11]. It turned out that at depths over $300 \mathrm{~m}$ in the top $20 \mathrm{~cm}$ is thicker sludge in places of prevalence of oxidation of methane over his education, at oxidation of $100 \mathrm{CH}_{4}$ $\mathrm{mkg} /\left(\mathrm{dm}^{3}\right.$ of days $)$ temperature of the environment increases on $2^{\circ} \mathrm{C} \div 3^{\circ} \mathrm{C}$ in day (Figure 7) [12].
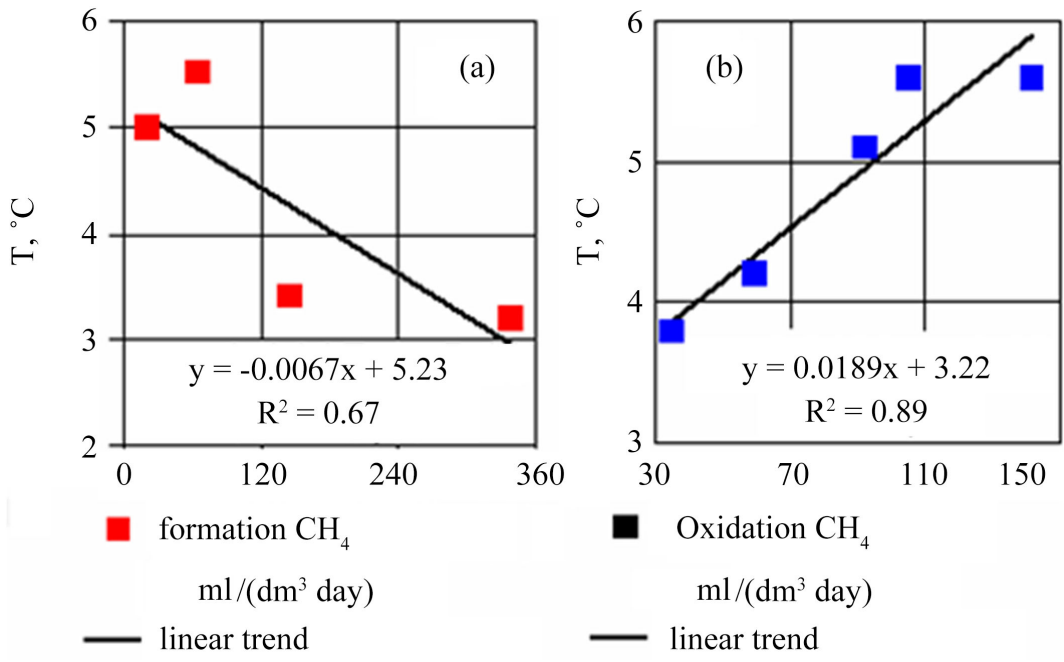

Figure 7. Temperature change in the silty soils of Baikal during the formation (a) and oxidation (b) of methane. 
It is known that the concentration of methane under the ice and in its lower layers exceeds the concentration at the surface of the ice by an order of magnitude [7]. This is due to both the accumulation of microorganisms under the ice that generate methane, and the fact that gaseous (bubble) methane rising to the surface (unlike hydrogen, whose molecules are much smaller in size) cannot massively "squeeze" through ice crystals and accumulate under the ice and in its lower layers. Energy released by mass oxidation of methane by microorganisms forms pores, converts monolithic ice into porous ice without noticeable reduction of its thickness (Figure 1).

\section{Methanotrophic Reduction of Arctic Ice Area}

In recent decades, there has been a tendency to stagnate the Arctic ice cover [13] [14]. By October, its area from 1980 to 2012 was reduced by a third (Figure 8). Researchers, with reservations, attribute this to climate warming. How can winter warming at temperatures below $-10^{\circ} \mathrm{C}$ lead to such a significant reduction in the area of drifting ice north of $75 \mathrm{~N}$ in the absence of a dumbbing ice removal from the Arctic-COLAPS PHYSICS?

In our opinion, in a region saturated with hydrocarbons, including hundreds of methane yields on the seabed, reaching a kilometer size, the current reduction in the area of drifting melting ice is associated with an increase in seismic activity (the number of earthquakes per year began to reach 100) (Figure 9) [15] [16] [17]. Analysis of the situation showed that for the detailed detection of the impact of seismogenic agitation and subsequent methanotrophy, earthquakes from May to September should be taken into account, with the exception of the waters north of $82 \mathrm{~N}$, where methanotrophic breeds are quickly dragged by drifting or newly formed ice (the sun is very low above the Earth), the waters to the around East Greenland, where ice drifts south.

With this approach, almost all background variations in the position of the ice edge in the East Siberian seas are explained from the position of methanotrophy. Namely, until 1989 and later in the seismic events of 1994, 1998, 1999 and 2001 in the Laptev Sea and the East Siberian Sea, insolation alone was not enough to melt the ice off the Novosibirsk Islands (Figure 10). Only after seismogenic

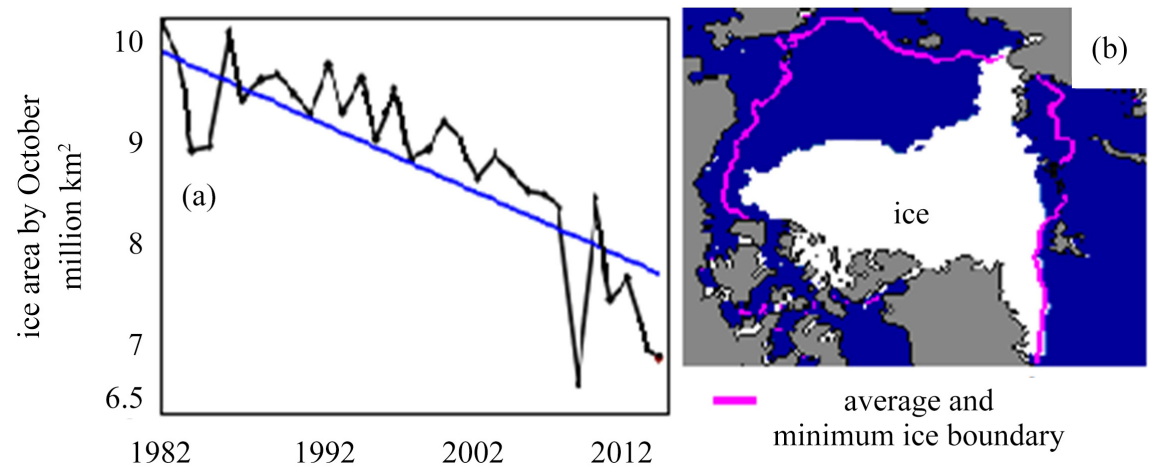

Figure 8. The annual course of the minimum ice area in the Arctic (a), the average ice boundary and the minimum 16.09.2007. (b). 


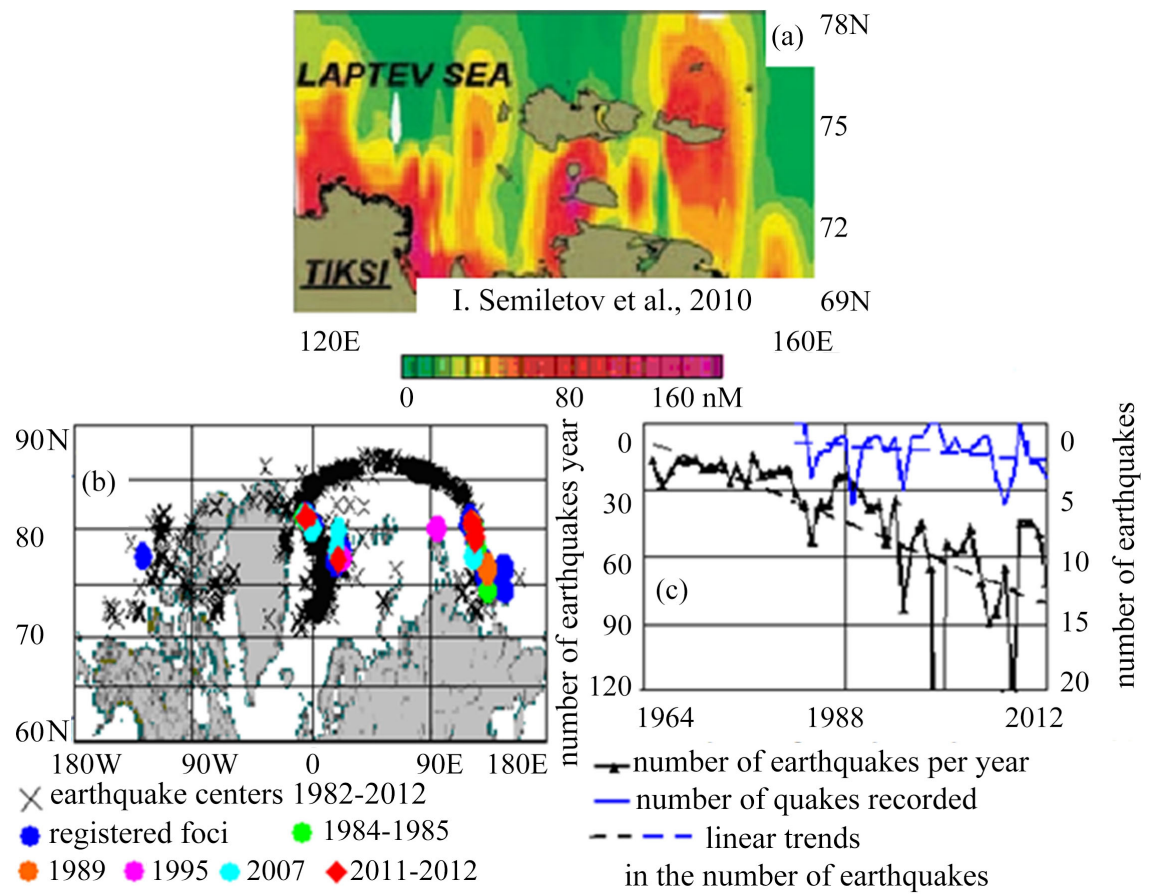

Figure 9. Concentration of methane in the East Siberian seas (a). Centers of all and recorded earthquakes (b), annual progress of the number of all and recorded earthquakes (c).
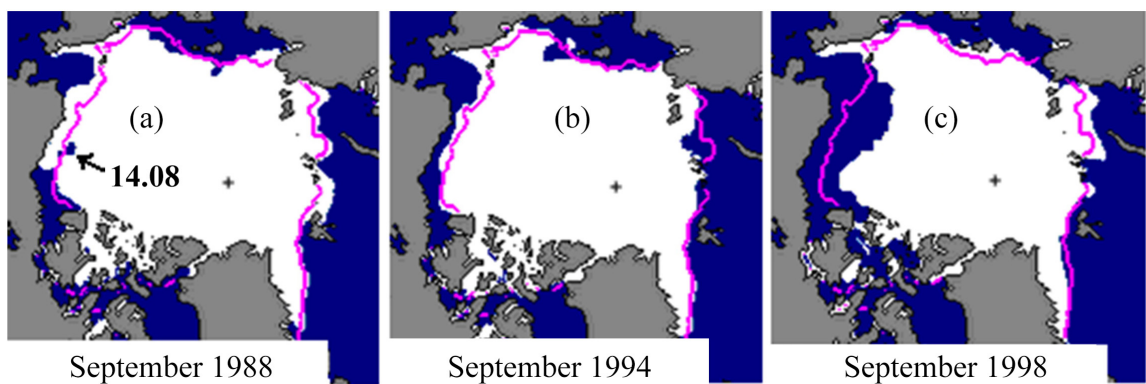

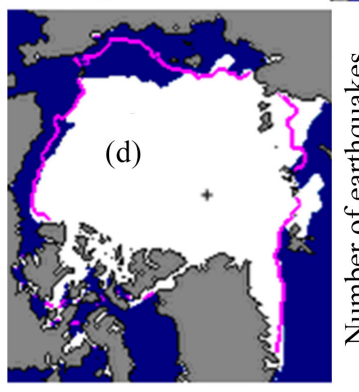

September 1989

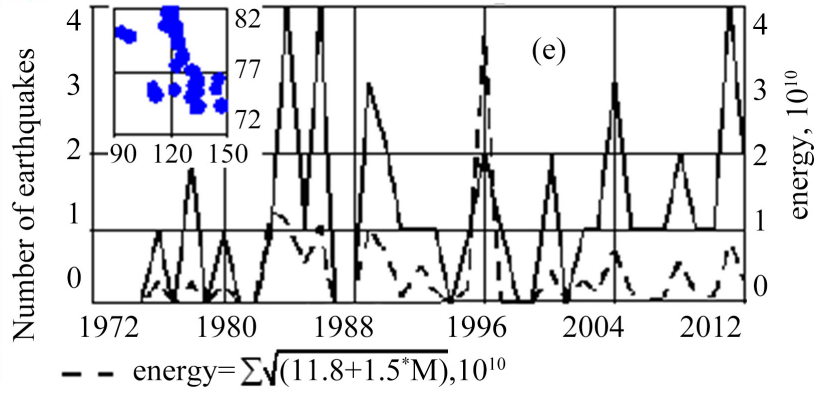

- Number of recorded earthquakes

Figure 10. Edge of ice in September in seismic years (a-c) and in seismoactive 1989 (d). Number of recorded earthquakes and their energy, on the tie-in of their epicenters (e).

treatment of ice with methane and detritus from the second half of May, starting in 1989, the East Siberian Sea began to free itself from ice by September. The change in ice cover is also associated with the destruction of pack ice due to the triple activation of earthquakes on the Gakkel ridge since 1965. Solar melting of 
ice is facilitated by seismogenic methanotrophy and rushing, the latter leads to the appearance on the surface of the ice of gray products of methanotrophy and detritus (raised by methane bubbles), which reduces the amount of albedo.

It is "more convenient" to identify seismogenic wormland in Arctic ice in moorland areas, since it is problematic to distinguish them from moorland fields off the coast [18].

It turns out that in the centers of earthquakes after 20 - 30 days, large-scale (over $500-5000 \mathrm{~km}^{2}$, according to low-resolution microwave information) stable wormwood that persists until October [4] [19]. In particular, this was the case after the August earthquake on the Alaskan shelf in 1988, after the July and August earthquakes of 2012 near $80 \mathrm{~N}$ in the Laptev Sea (Figure 11). "Maintains" their quasi stability of methane and the detritus of aftershocks. Presence of mass of the small detrit is significant for ice thawing as detrit, gravitationally slowly (for $20 \div 50$ day) being besieged from a cold fotichesky layer, utonchy him, promotes heating of surface water on $2^{\circ} \mathrm{C} \div 3^{\circ} \mathrm{C}$ [12]. Seismogenic processes that contribute to the melting of ice occur not only in the centers of earthquakes, but also over the faults of the earth's crust [15].

Seismogenic wormwood away from the western wormwood were observed earlier, for example, on the map 13.06.1951 at the earthquake center 29.04.1051 with a magnitude of 5.2 (Figure 12(a)) [20] [21]. There is so much methane in the region that even in permafrost conditions, January coastal earthquakes (06.01.2007, $73.7 \mathrm{~N}, 125.5 \mathrm{E}, \mathrm{M}=3.2 ; 08.01 .200771 .1 \mathrm{~N}, 142.6 \mathrm{E}, \mathrm{M}=2.2$ ) [22] are accompanied by methane mass inflows to the lower troposphere (Figure 12(b)).

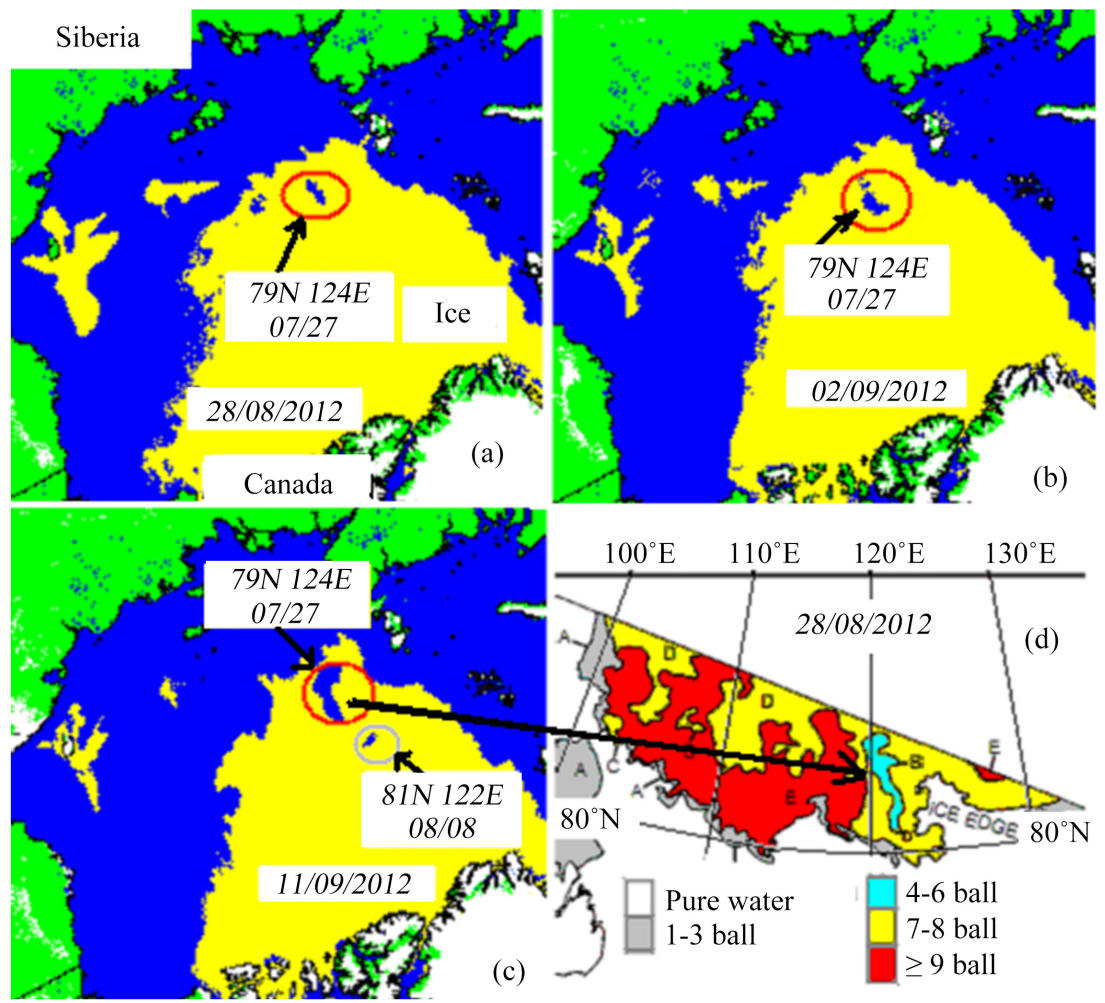

Figure 11. Seismogenic wormwood in the Arctic ice sheet. 


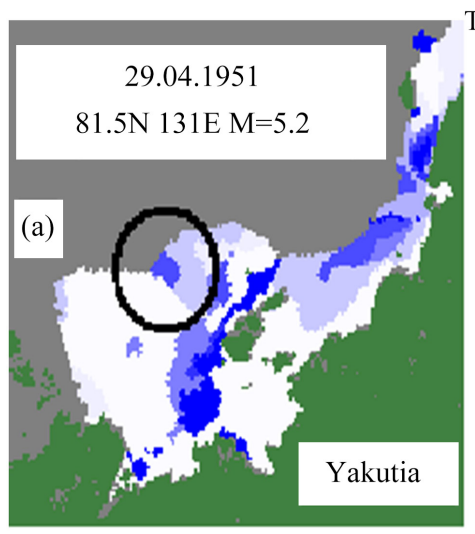

TES L3 Daily Plot: $\mathrm{CH}_{4}$ at $681.3 \mathrm{hPa}$, Nadir, 01/09-01/10 2007 runID $=5188, \operatorname{minVal}=1.6 \mathrm{ppmv}, \operatorname{maxVal}=1.9 \mathrm{ppmv}$

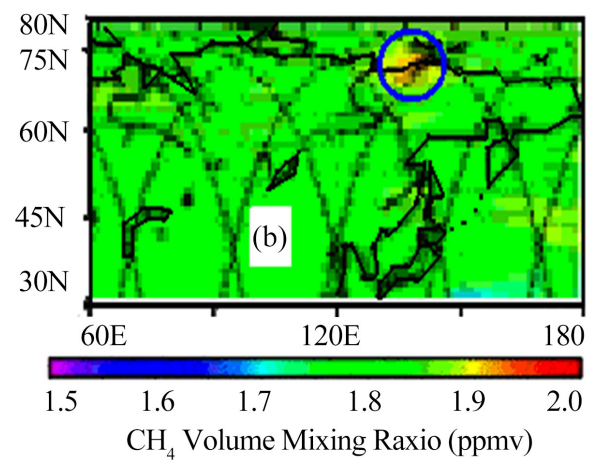

Figure 12. Wormwood (in a black circle) at the center of the earthquake on the ice map 13.06.1951 (a). Methane content in the lower troposphere 9-10.01.2007 (in the blue ellipse, a methane flash in the area of the Yakut littoral) (b).

\section{Reducing Arctic Ice Thickness}

The area of long-term ice from 1980 to 2015 was almost completely determined by the area of ice preserved from last summer (Figure 13).

At the turn of the 70s - 80s of the XX century, fragmented ice and thermal anomalies did not coincide in the Arctic. The ice thickening on $30-50 \mathrm{~cm}$ occurred it against the background of warming of the Arctic air on $1^{\circ} \mathrm{C} \div 2^{\circ} \mathrm{C}$ (as in the polar atmosphere in general, and regionally on $\mathrm{m}$ of Barrow and in the item Tiksi) (Figure 14, Figure 15) [7] [12] [23] [24] [25]. The cooling that came in 1982-1987 did not lead to the expected thickening of the ice, but on the contrary. The whole thing is seismic calm from 1977 to 1981, there was no mass seismodegasation of methane, methanotrophic microorganisms organisms did not actively drill the ice. The temporary thickening of ice of $\approx 10 \%$ in $2004 \div 2006$ also was on was a consequence of stagnation of seismic activity from 2002 to 2006 .

\section{Seismogenic Wormwood in the Southern Ocean}

Abnormalities of methanotrophic-detritus genesis in the ice cover are ubiquitous. They are also observed in the Southern Ocean after earthquakes (Figure 16) [26].

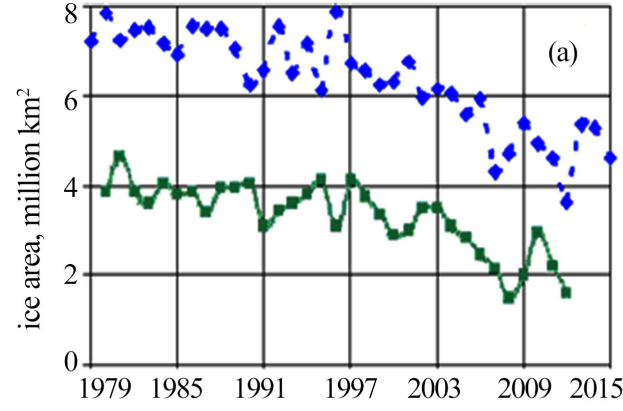

- - minimum ice area in September, million $\mathrm{km}^{2}$ $\rightarrow-$ minimum long-term ice area, million $\mathrm{km}^{2}$

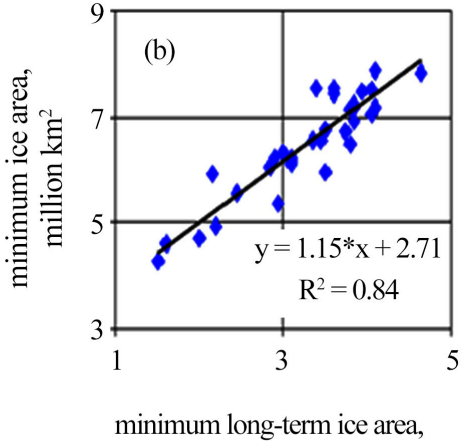

year ago shift, million $\mathrm{km}^{2}$

Figure 13. The time course of the minimum area of all ice and perennial in September (a). Comparison of the areas of these ice with the annual shift (b). 


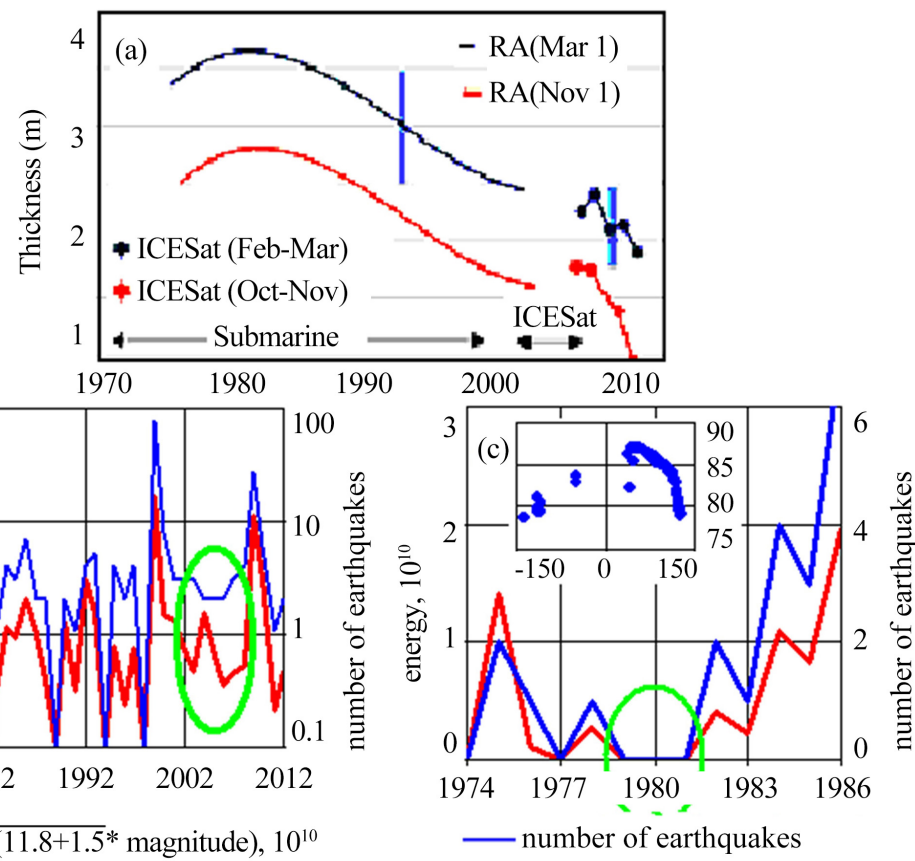

Figure 14. Thickness of spring and autumn ice (a). The energy and number of quakes recorded from 1972 to 2012 (b) and from 1974 to 1986. At the tie-in, the epicenters of earthquakes for 1972-2012 (c).

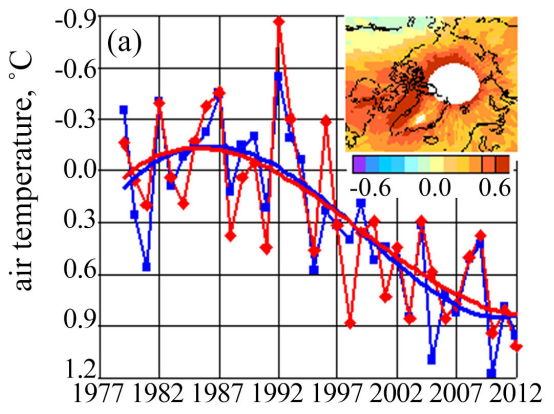

air temperature, ${ }^{\circ} \mathrm{C} \rightarrow$ aver year $\rightarrow 6-9$ mes

— polynomial trend (year)

— polynomial trend (6-9 months)

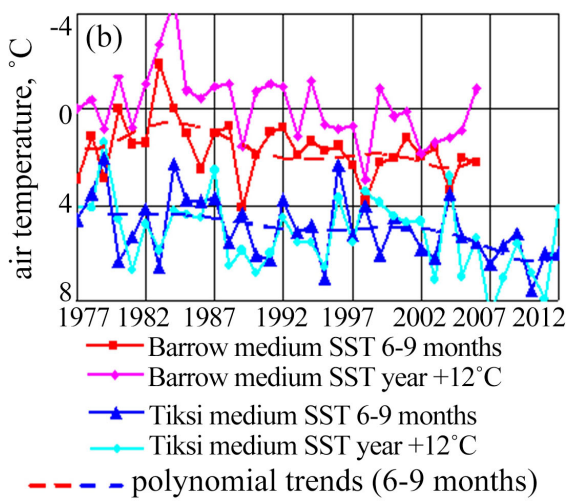

Figure 15. Air temperature anomalies in the lower troposphere in polar latitudes for the year and for 6 - 9 months. On the tie-in, the mapped temperature trend (a). The average temperature for the year and for 6 - 9 months at $\mathrm{m}$. Barrow and in the village of Tixi (b). 


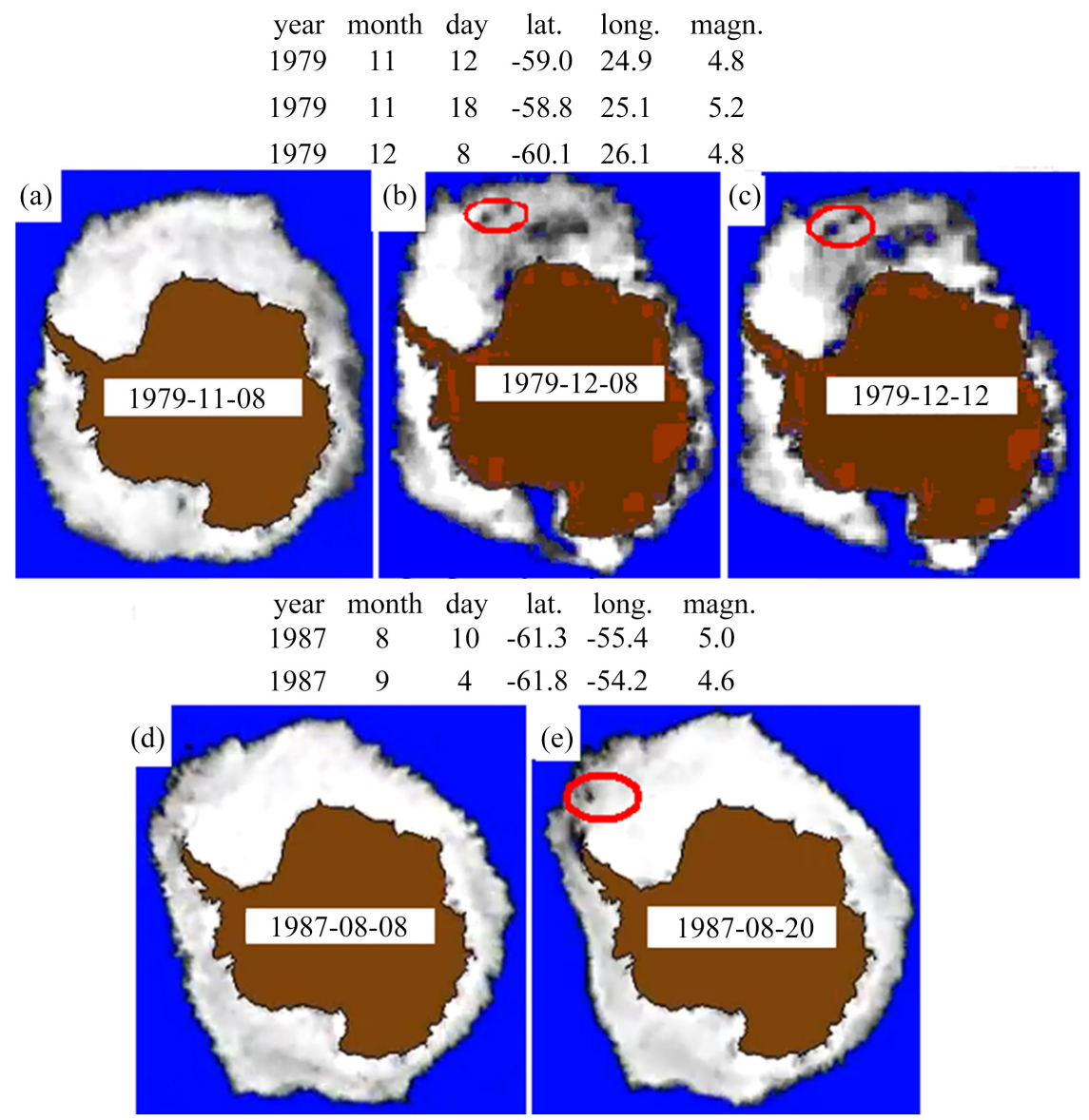

Figure 16. Seismogenic wormwood in Antarctic ice. Terms and coordinates of earthquake epicenters are indicated at the top.

Since seismic activity in the Southern Ocean is order of magnitude less intense than in the Arctic, and one-year ice prevails, there are no large-scale significant annual changes. Over the past 40 years, the water surface temperature has changed from year to year by less than $0,5^{\circ} \mathrm{C}$ in the absence of unambiguous annual trends [27].

\section{Conclusions. Development of Ice Cover under Seismogenic Conditions}

In the regulatory documents on ice, all recommendations and calculation methods relate mainly to monolithic ice with micropores. For ice with pores of size $\mathrm{cm}$ there is no indication of its genesis, the rate of conversion of monolithic ice to porous ice and its strength.

The situation with ignoring the bacterial oxidation of methane developed at the initial stage of the development of hydrometeorology [1] [28] [29], when the study of methane accumulations was carried out exclusively by marine geologists [6] [7]. The means of remote sensing of the Earth have not been developed, earthquakes are rare, and systems for collecting and disseminating information about them have been departmental in nature. As a result, and at present, due to the lack of references in regulatory documents to methanotrophic melting of ice, 
it is "more convenient" to drown everything in snowy bubble ice than, except for regular observations of ice temperature and thickness, measure ice strength, methane and oxygen concentration in the medium.

The formation in the waters of vast western wormwood is mainly due to the activation of seismogenic degassing and methanotrophy. Bacterial oxidation of methane converts monolithic ice into porous ice. When rushing, dark products of methanotrophy and detritus raised by gas bubbles appear on the surface of the ice. The albedo of the ice surface decreases, contributing to its melting and the formation of dilutions. The early melting of ice in dilutions and their transformation into vast wormwood is due to methanotrophy products and seismogenic small detritus, which gravitationally slowly settling out of the cold photic layer, thinning it, contributes to an additional insolation warm-up of $2^{\circ} \mathrm{C} \div 3^{\circ} \mathrm{C}$, freeing the waters from ice months earlier than normal. This is recorded everywhere from the Sea of Okhotsk to the Arctic and the Southern Ocean. In the Arctic, the activation of seismogenic methanotrophy has reduced the area of perennial and pack ice several times.

Can methanotrophic melting be used for economic purposes? To prevent ice congestion in silty reservoirs, atmospheric air should be pumped a decade before ice flow under the ice (closing holes and cracks with snow and ice). As a result of methanotrophy, monolithic ice will turn into weakened, porous. With the insufficient concentration of natural silts at the bridge supports under them in the fall and at the end of winter, it is necessary to store silt from the nearest swamps. To strengthen transitions through frozen reservoirs, frequent holes should be made along the transitions to outflow methane. The proposed technologies will allow removing extremely toxic methane from aerobic hydrobionts, saturating water with oxygen instead of spring explosives.

To guide ships through heavy ice, bottom mines can be detonated on the route in a week. Methane released from the sediment will turn into weakened, porous. Hydrobionts in the Arctic in winter are not much so the damage from their death in the point will exceed the negative consequences of burning fuel.

In order to move from the state of the Arctic ice (and climatic changes on Earth) to the forecast, the joint variability of seismic activity in the Arctic and the activity of the Sun should be analyzed.

\section{Conflicts of Interest}

The authors declare no conflicts of interest regarding the publication of this paper.

\section{References}

[1] Oceanological Tables (1975) Hydrometeoisdat, Leningrad, 477 p. http://elib.rshu.ru/files_books/pdf/img-515135037.pdf

[2] ftp://14ftl01.larc.nasa.gov/TES/

[3] http://www.scanex.ru/

[4] http://www.ncedc.org/anss/catalog-search.html 
[5] Sytinsky, A.D. (1987) Connection of Earth's Seismicity with Solar activity and Atmospheric Processes. Gidrometeoizdat, Leningrad, 99 p.

[6] Oceanology (1979) Ocean Chemistry, Vol. 1, Science, Moscow, 518 p.

[7] Lein, A.Y. and Ivanov, M.V. (2009) Ocean Methane Biogeochemical Cycle. Science, Moscow, 576 p.

[8] Galchenko, V.F. (2001) Methanotrophic Bacteria. GEOS, Moscow, 500 p.

[9] Egorov, V.F., Polikarpov, G.G., Gulin, S.B., Artemov, Yu.G., Stokozov, N.A. and Kostova, S.K. (2003) Modern Ideas about the Medium-Forming and Ecological Role of Jet Methane Gas Releases from the Bottom of the Black Sea. Sea Ecologic Magazine, 2, 3-26.

[10] Rozhirov, A.I. (2008) Migration of Hydrocarbons from the Subsoil to the Surface and Formation of Oil and Gas Deposits and Gas Hydrates in the Sea of Okhotsk during the Period of Seismic and Tectonic Activations. Materials of the All-Russian Conference "Degassing of the Earth: Geodynamics, Geofluids, Oil, Gas and Their Parageneses", Moscow, 22-25 April 2008, 359-362.

[11] Dagurova, O.P., Namsaraev, B.B., Kozyreva, L.P., Zemskaya, T.I. and Dulov, L.E. (2004) Bacterial Processes of the Methane Cycle in the Bottom Sediments of Lake Baikal. Microbiology, 73, 248-257.

[12] Lyushvin, P.V. (2016) Genesis of Polar Climatic Changes. XX1Y Meeting of the All-Russian Interdisciplinary Seminar-Conference of the Geological Faculty of Moscow State University "Earth System”, Moscow, 2-4 February 2016.

https://youtu.be/fePKDQ9nL0k

https://www.youtube.com/watch?v=nbh-cGovSvI

[13] https://www.ncdc.noaa.gov/snow-and-ice/extent/sea-ice/N/9

[14] https://nsidc.org/data/seaice_index/archives/image_select

[15] Baranov, Yu.B., Kozhina, L.Yu., Cherkasov, V.A., Krasnyntsev, V.A., Zatyagolova, V.V. and Kruglyakova, R.P. (2013) Experience of Studying Natural Hydrocarbon Yields to the Marine Environment Based on a Comprehensive Analysis of Satellite and Satellite Observations. Collection of Abstracts of Reports of the All-Russian Conference with International Participation, Arkhangelsk, 17-19 September 2013, 178-179.

[16] Valyaev, B.M. (2011) Degassing of the Earth and Processes in the Biosphere. 6th International Conference on Environmental Micropaleontology, Microbiology, and Meiobenthology, Moscow, St. Petersburg, 19-22 September 2011, 135-145.

[17] Semiletov, I.P. (2020) Methane over the Arctic. https://www.youtube.com/watch?v=R8-27EdbXzg

[18] Atlas of Biological Diversity of the Seas and Coasts of the Russian Arctic (2011) World Wide Fund for Nature, Moscow, $64 \mathrm{p}$.

[19] https://masie_web.apps.nsidc.org/pub//DATASETS/NOAA/G02135/north/daily/im ages/

[20] Kondorskaya, R.N.V. and Ulomov, V.I. (1999) Special Catalogue of Earthquakes of Northern Eurasia (SECNE) from Ancient Times through 1995. Joint Institute of Physics of the Earth (JIPE), Russian Academy of Sciences, Moscow.

[21] ftp://ftp.gsras.ru/pub/Regional_Catalogs/2007/yakutiya/cat0607.rtf

[22] ftp://sidads.colorado.edu/pub/DATASETS/seaice/

[23] http://gaw.kishou.go.jp/wdcgg/

[24] http://www.aari.ru/main.php?lg=0

[25] http://www.ssmi.com/msu/msu_time_series.html 
[26] http://www.youtube.com/watch?v=y3FSvtvKGlA

[27] Kotenev, B.N., Krovnin, A.S., Maslennikov, V.V., Mordasova, N.V. and Muryi, G.P. (2020) Prospects for the Development of World Fisheries in Connection with Climate Change. Scientific Notes of the Russian State Hydrometeorological University, No. 48, 167-185.

https://readera.org/perspektivy-razvitija-mirovogo-rybolovstva-v-svjazi-s-izmeneni em-klimata-140228910

[28] Maximov, I.V., Sarukhanyan, E.I. and Smirnov, N.P. (1970) Ocean and Space. Hydrometeoisdat, Leningrad, $216 \mathrm{p}$.

[29] Frolov, I.E., Ashik, I.M., Baskakov, G.A. and Kirilov, S.A. (2011) Russian Marine Research of the Arctic-Past and Present. Problems of the Arctic and Antarctic, No. 4, 1-11. 